Agro-Science Journal of Tropical Agriculture, Food, Environment and Extension Volume 10 Number 3 Sentember 2011 nn $28-37$

ISSN 1119-7455

\title{
PHOSPHORUS FORMS AND DISTRIBUTION IN SELECTED SOILS FORMED OVER DIFFERENT PARENT MATERIALS IN ABIA STATE OF NIGERIA
}

\author{
Ohaeri ${ }^{1}$ J. E. and Eshett ${ }^{2}$ E. T. \\ 1. National Root Crops Research Institute Umudike, Abia State, Nigeria. \\ 2. Department of Soil Science and Technology, Federal University of Technology, Owerri, \\ Nigeria.
}

\begin{abstract}
The forms and distribution of phosphorus in selected soils formed over different parent materials in Abia State of Nigeria were investigated. Total P varied widely ranging from 175.6 to $1252.45 \mathrm{mg} / \mathrm{kg}$ with overall mean of $450.68 \mathrm{mg} / \mathrm{kg}$. Ajata soils having higher values while Amakama have lower values. The organic $P$ also varied widely ranging from 31.03 to $127.71 \mathrm{mg} / \mathrm{kg}$ with a mean value of 61.0 and $92.91 \mathrm{mg} / \mathrm{kg}$ respectively. About $40 \%$ of the Total $P$ in the surface horizon (Ap) of the finetextured soils (Ajata) are in organic P form while the coarse-textured soils (Amakama) have a very low $(<20 \%)$ organic $P$ contribution to total $P$. The inorganic fractions of the soils occurred in the sequence of occluded $P>F e-P>A l-P>C a-P$. The occluded $P$ constitutes between 26 and $68 \%$ of the total $P$ in the various soils and 40 to $80 \%$ of the total inorganic $P$. The occluded $P$ and $F e-P$ comprise more than $84 \%$ of the total inorganic P. The content of Ca-P and Al-P were very low $(<16 \%$ of the total inorganic $P)$. The active inorganic $P$ constitutes between 18 and $38 \%$ of the total $P$. There is high content of Al-P in the lower horizons of the Ajata soil. Available P is low with values ranging from $4-21 \mathrm{mg} / \mathrm{kg}$ with a mean value of $11.59 \mathrm{mg} / \mathrm{kg}$. The surface horizon (Ap) contains more available $P$ than the subsurface soil horizons. The multiple correlation analysis revealed that total $P$ correlated negatively with sand and positively with clay, exchangeable Ca, occluded P, organic P, Ca-P, Fe-P. Organic P correlated positively with Fe-P, Al-P and total P. Ca$P$ correlated negatively with sand and positively with organic carbon, exchangeable $C a, A l-P$ and total P. Fe-P correlated positively with organic P, Al-P and total P. Al-P correlated positively with $F e-P, C a-P$ and organic $P$. The occluded $P$ correlated positively with clay and exchangeable $C$ a and negatively with sand and $\mathrm{pH}$.
\end{abstract}

\section{INTRODUCTION}

Phosphorus is an essential element in the macro- element group and is therefore vital to plant growth. In most Nigerian soils, nitrogen, phosphorus, potassium, and magnesium and to some extent sulfur and zinc are the nutrients whose deficiencies most frequently limit the crop yield. That of $\mathrm{P}$ is further compounded by the highly weathered nature of the soils which are in the most areas acidic with high content of sesquioxides, Kaolinitic clays and exchangeable $\mathrm{Al}^{3+}$ which fix P (PPI, 1988). Several authors have characterized the $\mathrm{P}$ content of some soils (Uzu et al., 1975; Udo and Ogunwale, 1977; Udo and Dambo, 1979) and their relative availability to crops (Enwezor, 1977; Adepetu, 1975; Ayodele, 1980) and P sorption studies (Udo and Uzu, 1972; Juo and Fox, 1974; Osodeke et al., 1992).

Major differences between crops in their ability to take up different forms of $\mathrm{P}$, numerous inorganic and organic forms of $\mathrm{P}$ that occur in soils as well as the wider variation in behaviour between soil types are some of the factors militating against proper understanding of $\mathrm{P}$ behaviours in soil.

The soils of Abia State of Nigeria are conveniently classified into groups based on morphology and degree of profile development (Jungerius, 1964).The Owerri/Umudike soil group which include Amakama Olokoro soils are Ultisols (Soil Survey Staff, 2006) and are classified as Nitosols (F.A.O./UNESCO, 1988). They are strongly acidic, low in C.E.C, low in base saturation and low in soil fertility level. They are highly leached upland ferralitic soils with kaolinite as dominant clay type. These soils are derived from Coastal Plain Sands and are low in total P (Uzu et al., 1975; Loganathan and Sotton,1987; Enwezor et al., 1990; Osodeke and Kamalu, 1992). The Ajata soils are derived from Shale and Sandstone parent material and are reddish to brown in colour with gravelly surface 
and high clay content and therefore poorly drained. Although they are acidic, they are relatively high in base saturation with inherent high fertility. These soils are Alfisols (Soil Survey Staff, 2006) and are classified as Luvisols (F.A.O./UNESCO, 1988).

The studies on the forms and distribution of various forms of $\mathrm{P}$ in soil provided useful information in assessing the available $\mathrm{P}$ status and measuring the degree of weathering in the soil. The content and distribution of the active inorganic form of $\mathrm{P}$ $(\mathrm{Fe}-\mathrm{P}, \mathrm{Al}-\mathrm{P}$ and $\mathrm{Ca}-\mathrm{P})$ in the soil are a useful index in assessing the $\mathrm{P}$ requirement of soils. Quantification of organic $\mathrm{P}$ is necessary to better understand the mineralization-immobilization turnover of $\mathrm{P}$ under particular environments and cropping systems in the soils. Adequate knowledge of total $\mathrm{P}$, various fractions of $\mathrm{P}$ of some important agricultural soils of Abia State of Nigeria, as well as, their distribution and availability to crops, is important in $\mathrm{P}$ management of these soils and fertilizer recommendation.

Most of the investigation carried on $\mathrm{P}$ status and forms in soils of Abia State were done on surface soils. There has not been any concerted effort to investigate $\mathrm{P}$ forms along the genetic horizons. Therefore the need to have a detailed study of the forms of $\mathrm{P}$ and their distribution with depth along the genetic horizons of the soils seems warranted. Therefore, the objective of this study is to evaluate the forms of $\mathrm{P}$, the pattern of their distribution with profile depth, as well as the relationship between these various forms of $\mathrm{P}$ in the selected soils of Abia State developed from different parent materials.

\section{MATERIALS AND METHODS}

The study was conducted at Amakama Olokoro and Ajata Ibeku, both in Abia State, Nigeria. A free survey method was used in the choice of sampling sites. The site was georeferenced using handheld Global Positioning System (GPS) Receiver (Garmin Ltd Kansas, USA). Pedon sampling was based on identified pedogenic horizons. A Profile Pit was dug in each of the 2 locations. The profiles were described and sampled following the procedures of Soils Survey Staff (2006). Eight soil samples were collected from each profile pit.

In the laboratory, the Soil samples were air-dried for 3 days at room temperature. They were gently crushed with a wooden roller and passed through a 2-mm sieve. A small portion of each sample were crushed with a mortar and passed through $0.5-\mathrm{mm}$ sieve for some analysis such as organic carbon, total $\mathrm{N}$, total $\mathrm{P}$ and organic $\mathrm{P}$. The particle size distribution was determined by Bouyoucos (1962) hydrometer method using sodium heaxmetaphosphate (calgon) as dispersing agents. The $\mathrm{pH}$ of the soil samples was determined in water and KCL by means of Bechman's pH meter using a soil water ration of 1:2.5 (Thomas, 1996). Organic carbon was determined by the procedure of Walkley and Black (1934) using the dichromate wet oxidation method (Nelson and Sommers, 1996). Total nitrogen was determined by the microkjedahl distillation method (Bremner, 1996). Exchangeable bases $(\mathrm{Ca}, \mathrm{Mg}, \mathrm{K}, \mathrm{Na}$ ) were extracted with $1 \mathrm{~N}$ Ammonium acetate $\left(\mathrm{NH}_{4} \mathrm{OAc}\right) \mathrm{pH}$ 7.0. $\mathrm{Ca}$ and $\mathrm{Mg}$ in the extracts were determined by titration (Jackson, 1958) while $\mathrm{Na}$ and $\mathrm{K}$ were determined with flame photometer. Exchangeable Hydrogen and $\mathrm{Al}$ were determined by the method outlined by Mclean (1982). Effective cation exchange capacity (ECEC) was calculated as the sum of total exchangeable bases (TEB) and total exchangeable acidity (TEA). Percentage base saturation was calculated as outlined by Coleman and Thomas (1967). Total phosphorus in the soils was determined by perchloric acid digestion (Jackson, 1958) and organic P was estimated by the difference between 13 M HCL extractable inorganic $\mathrm{P}$, before and after ignition, by the method of Leg and Black (1955). Inorganic $\mathrm{P}$ was fractionated by method of Chang and Jackson (1957) as modified by Peterson and Corey (1966). Available P was extracted by Bray and Kurtz No. 2 extractant (Bray and Kurtz, 1945), Phosphorus in the extracts was determined colorimetrically (Murphy and Riley, 1962). The results obtained were subjected to statistical analysis using statistical computer package of GenStat Release computer (2011).

\section{Determination of phosphorus as aluminum phosphate (Al-P)}

One gram of air dried soil ( $2 \mathrm{~mm}$ sieve) was weighed out placed in $250 \mathrm{ml}$ plastic container. $35 \mathrm{ml}$ of $\mathrm{I} \mathrm{N} \mathrm{NH} \mathrm{N}_{4} \mathrm{Cl}$ was added and the mixture shaken on a mechanical shaker for 30 minutes. To remove water soluble and loosely bound $\mathrm{P}$ and exchangeable $\mathrm{Ca}$, the suspension were filtered (Whatman filter paper No. 42) and the filtrate discarded, leaving the soil residues. To the residues in the plastic bottle were added $35 \mathrm{ml}$ of $0.5 \mathrm{~N} \mathrm{NH}_{4} \mathrm{~F}$, covered tightly and shaken for $1 \mathrm{hr}$ on a mechanical shaker. The mixture was filtered and the clear filtrates were used for Al-P determination. The soils residues in the plastic bottle were reserved for Fe-P extraction. For Al-P determination, aliquots $(10 \mathrm{ml})$ of the extract were pipetted out into $50 \mathrm{ml}$ volumetric flask and $15 \mathrm{ml}$ boric acid added $(0.8 \mathrm{M})$. Blue colour was developed using 
$4 \mathrm{ml}$ of reagent B solution and made up to mark with distilled water. Absorbance readings were recorded at $880 \mathrm{~nm}$ wavelength using the UV/VIS Unicam spectro-colorimeter.

\section{Phosphorus determination as iron phosphate (Fe- P)}

The soil residue saved after Al-P extraction was washed twice with $25 \mathrm{ml}$ saturated $\mathrm{NaCl}$ and filtered each time and the filtrate discarded. Thereafter, $35 \mathrm{ml}$ O.I N NaOH was added to the plastic bottles, covered tightly and shaken for 17 hours. The suspensions were filtered and clear extract collected for $\mathrm{Fe}-\mathrm{P}$ determination. The soil residues in the plastic bottle were reserved for $\mathrm{Ca}-\mathrm{P}$ extraction. For $\mathrm{Fe}$ $-\mathrm{P}$ determination, $5 \mathrm{ml}$ aliquot of the clear solution was pipetted into $50 \mathrm{ml}$ volumetric flask, $4 \mathrm{ml}$ of reagent $\mathrm{B}$ was added for the blue colour development and made up to mark with distilled water. Absorbance readings were recorded at $880 \mathrm{~nm}$ wavelength using a UV/VIS Unicam spectro-colorimeter.

\section{Phophorus determination as calcium phosphate (Ca-P)}

The soil residues saved after the Fe-P extraction was washed twice with $25 \mathrm{ml}$ saturated $\mathrm{NaCl}$ solution (10\%), filtered each time and discarded, $35 \mathrm{ml}$ of $0.5 \mathrm{~N} \mathrm{H}_{2} \mathrm{SO}_{4}$ was added to the soil in the plastic bottles, covered tightly and shaken on the mechanical shaker for I hour. The suspensions were filtered and clear solution obtained. $30 \mathrm{ml}$ aliquot of the clear solution was pipetted into $50 \mathrm{ml}$ of volumetric flask, $4 \mathrm{ml}$ of the reagent $\mathrm{B}$ was added for colour development and the volume made up to mark with distilled water. Absorbance readings were recorded at $880 \mathrm{~nm}$ wavelength using a UV/VIS Unicam spectro-colorimete.

\section{Determination of total phosphorus}

One gram of finely ground $(0.5 \mathrm{~mm}$ scene) soil was weighed out each into $250 \mathrm{ml}$ conical flasks and $25 \mathrm{ml}$ of $\mathrm{HNO}_{3}, 4 \mathrm{ml}$ of perchloric acid and $2 \mathrm{ml}$ of $\mathrm{H}_{2} \mathrm{SO}_{4}$ added respectively and mixed thoroughly. It was digested on a heater inside a fume cupboard until the colour due to organic matter disappeared. Then additional 20 minutes heating was allowed to dry completely. At this stage heavily white fumes due to $\mathrm{HNO}_{3}, \mathrm{HClO}_{4}$ and $\mathrm{H}_{2} \mathrm{SO}_{4}$ appeared and the insoluble materials looked like white sand. The flask was shaken occasionally during digestion. The digest was allowed to cool and 70 $\mathrm{ml}$ of distilled water was added to the digest and heated to warm. The suspension was filtered into $250 \mathrm{ml}$ volumetric flask and made up to mark with distilled water. Then, $10 \mathrm{ml}$ aliquot was pipetted into $50 \mathrm{ml}$ volumetric flask, $4 \mathrm{ml}$ of the reagent $\mathrm{B}$ was added and made up to mark with distilled water. The absorbance reading was recorded at $880 \mathrm{~nm}$ wavelength using a UV/VIS Unicam spectro-colorimeter.

\section{Determination of organic phosphorus}

One gram of finely ground $(0.5 \mathrm{~mm}$ sieve) soils were weighed into crucible placed in a cool muffle furnace. The temperature of the furnace was increased at $550^{\circ} \mathrm{c}$ and maintained for $1 \mathrm{hr}$. The crucible with the ignited soil samples were allowed to cool and soil transferred carefully to $250 \mathrm{ml}$ plastics bottles. Comparable unignited soil samples were weighed into similar bottles. The plastic bottles containing both ignited and unignited samples were added $10 \mathrm{ml}$ of $13 \mathrm{M} \mathrm{HCl}$ and heated in water bath for 10 minutes. The bottles were then removed from the water bath and an additional $10 \mathrm{ml}$ of concentrated $\mathrm{HCl}(13 \mathrm{M})$ added to each bottle and allowed to cool at room temperature for 1 hour. $15 \mathrm{ml}$ of distilled water was added to each bottle, mixed thoroughly and filtered. The extracts were collected into $100 \mathrm{ml}$ volumetric flask and made up to mark with distilled water. Thereafter, $15 \mathrm{ml}$ of aliquot was pipetted into 50 $\mathrm{ml}$ volumetric flask. $4 \mathrm{ml}$ of reagent $\mathrm{B}$ was added and made up to mark with distilled water. The absorbance reading was recorded for both ignited and unignited extracts at $880 \mathrm{~nm}$ wavelength using a UV/VIS Unicam spectrocolorimeter and the difference in phosphorus between the ignited and unignited samples were taken as the organic phosphorus content of the samples.

\section{Determination of occluded phosphorus}

The occluded phosphorus (inactive P) was calculated as the difference between the total phosphorus and the active phosphorus (Al$\mathrm{P}, \mathrm{Fe}-\mathrm{P}, \mathrm{Ca}-\mathrm{P})$.

\section{RESULTS AND DISCUSSIONS}

The site characteristics, as well as the results of morphological, physical, and chemical properties of the soils are given in Tables 1, 2, 3, and 4 respectively.

\section{Total phosphorus}

As show in Tables 6, the total P content in the entire study area varied widely ranging from 175.6 to $1252.45 \mathrm{mg} / \mathrm{kg}$ with the mean value of $450.68 \mathrm{mg} / \mathrm{kg}$. This is in agreement with the report of Uzu et al. (1975). The Ajata soils, derived from Clay Shale, contain the highest amount of total P (1252 mg/kg). The Amakama soils contain the lowest amount of total $\mathrm{P}$ among the two soil profiles studied $(301 \mathrm{mg} / \mathrm{kg})$. This is also in agreement with the report of Uzu et al., (1975). The Amakama soil, derived from 
Coastal Plain Sands has a total $\mathrm{P}$ which ranged from 175.6 to $301.2 \mathrm{mg} / \mathrm{kg}$ with a mean of 237.5 $\mathrm{mg} / \mathrm{kg}$ from $0-240 \mathrm{~cm}$ depth. These values are comparable with values obtained by Loganathan and Sutton (1987) in the Coastal Plain Sands of Rivers State. They are, however higher than the values reported by Osodeke and Kamalu (1992) in the Coastal Plain Sands of Eastern Nigeria rubber growing zones, and also the values obtained by Loganathan et al., (1982) in Ultisols and Alfisols of coconut growing soils of Sri Lanka. The high total $\mathrm{P}$ in Ajata soils is a reflection of the high phosphate content of the parent rock from which the soils were formed (Akamigbo and Asadu, 1983). Total P correlated positively with clay and negatively with sand (Table 7). This is in agreement with reports of Osodeke and Kamalu (1992). Total P also correlated positively with exchangeable calcium, Ca-P, Al-P, occluded $\mathrm{P}$ and Organic P. However, there was no significant correlation between total $\mathrm{P}$ and $\mathrm{pH}$ on the one hand and organic carbon on the other hand. This was also reported by Osodeke and Kamalu (1992). The pattern of distribution of total $\mathrm{P}$ with depth was not uniform in all the soils studied (Udo and Dambo, 1979; Enwezor, et al., 1991; Brady and Weli, 2002).

Organic $P$ contents in the soils Organic P contents in the soils varied widely depending upon the parent material with the lowest being recorded in the Amakama soil $(31.03 \mathrm{mg} / \mathrm{kg})$ while the highest was found in the Ajata soil (127.71 $\mathrm{mg} / \mathrm{kg}$ ) with a mean values of 61.0 and $92.91 \mathrm{mg} / \mathrm{kg}$ in the Amakama and Ajata soils, respectively (Table 5). These values constitute 25.6 and 13.9 percent, respectively of the total $\mathrm{P}$ in these soils. These values are lower when compared with the values of 34 to $339 \mathrm{mg} / \mathrm{kg}$ and 30 to 900 $\mathrm{mg} / \mathrm{kg}$ reported by Loganathan and Sutton (1987) in the Coastal Plain Sands of Rivers State and by Uzu et al., (1975) in the soils of Southeastern Nigeria respectively; but comparable with the value of 1.0 to 90 $\mathrm{mg} / \mathrm{kg}$ and 28.88 to $88 \mathrm{mg} / \mathrm{kg}$ reported by Lognathan et al. (1982), and Osodeke and Kamalu (1992). About $40 \%$ of the total P in the surface horizon (Ap) of the fine textured soils (Ajata soils) are in organic $\mathrm{P}$ form (Uzu et al., 1975; Enwezor et al., 1990; Osodeke and Kamalu, 1992). However, the coarse textured soils (Amakama soils) have a very low $(<20 \%)$ Organic P contribution to the total P. The low Organic P of these coarse textured soils is a reflection of the low total $\mathrm{P}$ and organic carbon of these soils.

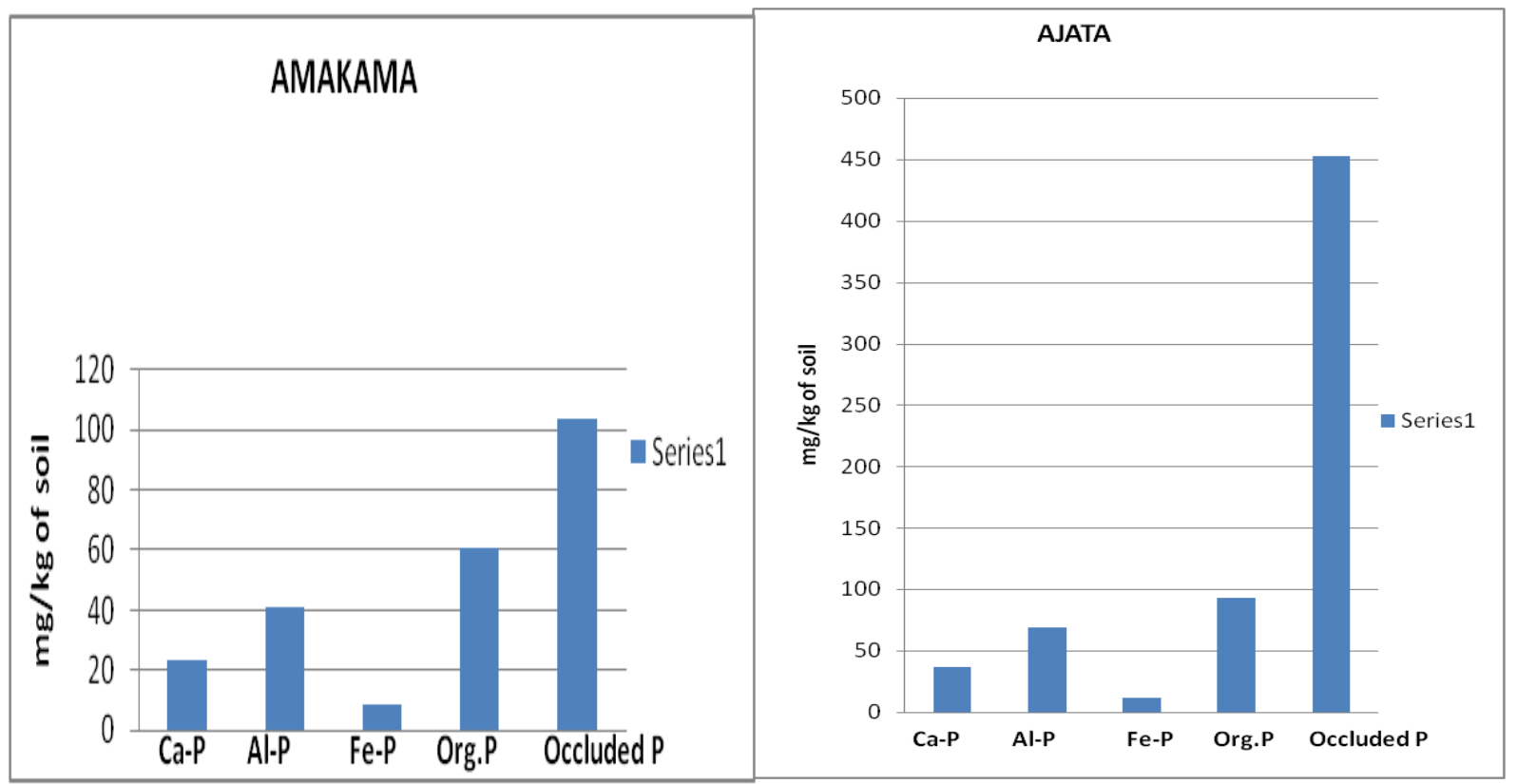

Fig. 1 Distribution of $\mathrm{P}$ forms 
Ohaeri J. E. and Eshett E. T.

Table 1: Sampling location, parent material, and vegetation of the sampling site

\begin{tabular}{|c|c|c|c|c|c|c|c|}
\hline Soils & $\begin{array}{l}\text { Classificatio } \\
\text { n usda }\end{array}$ & $\begin{array}{l}\text { Sampling } \\
\text { Location }\end{array}$ & $\begin{array}{c}\text { Parent } \\
\text { material }\end{array}$ & vegetation & $\begin{array}{c}\text { D } \\
\text { draina } \\
\text { ge }\end{array}$ & location & $\begin{array}{c}\text { mar } \\
(\mathbf{m m})\end{array}$ \\
\hline $\begin{array}{l}1 \text { Amakama } \\
\text { Olokoro } \\
2 \text { Ajata Ibeku }\end{array}$ & $\begin{array}{l}\text { Ultisols } \\
\text { Alfisols }\end{array}$ & $\begin{array}{l}\text { Umuahia } \\
\text { Umuahia }\end{array}$ & $\begin{array}{l}\text { Coastal } \\
\text { Plain sands } \\
\text { Clay shale }\end{array}$ & $\begin{array}{l}\text { Secondary } \\
\text { forest } \\
\text { Secondary } \\
\text { forest }\end{array}$ & $\begin{array}{l}\text { Well } \\
\text { drained } \\
\text { Poorly } \\
\text { drained }\end{array}$ & $\begin{array}{l}\text { Lat. } 5^{0} 26^{\prime} 40^{\prime \prime} \mathrm{N} \\
\text { Long: } 7^{0} 28^{\prime} 49^{\prime \prime} \mathrm{E} \\
\text { Lat: } 5^{0} 32^{\prime} 5^{\prime \prime} \mathrm{N} \\
\text { Long: } 7^{0} 33^{\prime} 34^{\prime \prime} \mathrm{E}\end{array}$ & 1976 \\
\hline
\end{tabular}

Table 2. Morphological properties of the soil profiles

\begin{tabular}{|c|c|c|c|c|c|c|c|c|c|}
\hline Désignation & $\begin{array}{l}\text { Depth } \\
\text { (cm) }\end{array}$ & $\begin{array}{l}\text { Colour } \\
\text { (moist) }\end{array}$ & $\begin{array}{l}\text { Colour } \\
\text { (dry) } \\
\text { Amakama O }\end{array}$ & $\begin{array}{l}\text { Texture } \\
\text { lokoro So }\end{array}$ & $\%$ slope), mi & Consistence & Pores & Roots & Boundary \\
\hline $\mathrm{Ap}_{2}$ & $13-27$ & $2.5 \mathrm{YR} 3 / 2$ & $7.5 \mathrm{YR} 4 / 4$ & SCL & $1, \mathrm{~m}, \mathrm{sbk}$ & fr,sst,spl & $1, \mathrm{f}$ & $\mathrm{m}, \mathrm{fb}$ & cs \\
\hline $\mathrm{B}_{1}$ & $27-63$ & $2.5 \mathrm{YR} 3 / 2$ & - & $\mathrm{SC}$ & $1, \mathrm{~m} . \mathrm{sbk}$ & fr,sst,spl & $3, \mathrm{f}$ & $\mathrm{m}, \mathrm{w}$ & gs \\
\hline $\mathrm{B}_{2}$ & $63-99$ & $2.5 \mathrm{YR} 3 / 6$ & - & $\mathrm{SC}$ & $1, \mathrm{~m} . \mathrm{sbk}$ & fr,sst,spl & $3, \mathrm{f}$ & $\mathrm{vf}, \mathrm{w}$ & gs \\
\hline $\mathrm{B}_{3}$ & $99-127$ & $2.5 \mathrm{YR} 4 / 6$ & - & $\mathrm{SC}$ & $1, \mathrm{~m} . \mathrm{sbk}$ & fr,sst,spl & $3, \mathrm{f}$ & $\mathrm{f}, \mathrm{w}$ & cs \\
\hline $\mathbf{B}_{4}$ & $127-159$ & $2.5 \mathrm{YR} 4 / 6$ & - & $\mathrm{SC}$ & 2,f,bsk & fr,sst,spl & $3, \mathrm{f}$ & $\mathrm{vf}, \mathrm{w}$ & cs \\
\hline $\mathrm{B}_{5}$ & $159-210$ & $2.5 \mathrm{YR} 4 / 6$ & - & $\mathrm{SC}$ & 2,f,bsk & fr,sst,spl & $3, \mathrm{f}$ & $\mathrm{vf}, \mathrm{w}$ & ds \\
\hline $\mathrm{B}_{6}$ & $210-240$ & $2.5 \mathrm{YR} 4 / 6$ & - & SCL & 2,f,bsk & fr,sst,spl & $3, \mathrm{f}$ & $\mathrm{vf}, \mathrm{w}$ & - \\
\hline \multicolumn{10}{|c|}{ Ajata Ibeku Soils, (0-5\% slope), upper slope. } \\
\hline $\mathrm{Ap}_{1}$ & $0-9$ & 10YR3/4 & 10YR5/4 & CL & $1, \mathrm{f}, \mathrm{cr}$ & Fr,sst,spl & $1, \mathrm{f}$ & $\mathrm{f}, \mathrm{fb}$ & Gs \\
\hline $\mathrm{Ap}_{2}$ & $9-28$ & $5 \mathrm{YR} 4 / 3$ & & $\mathrm{C}$ & $2, \mathrm{~m}, \mathrm{sbk}$ & Fr,sst,spl & $1, \mathrm{f}$ & $\mathrm{f}, \mathrm{fb}$ & Gs \\
\hline $\mathrm{Bt}_{1}$ & $28-60$ & $5 Y R 4 / 6$ & - & $\mathrm{C}$ & $2, \mathrm{~m}, \mathrm{sbk}$ & Fr,sst,spl & $2, \mathrm{f}$ & $\mathrm{f}, \mathrm{fb}$ & Gs \\
\hline $\mathrm{Bt}^{2}$ & $60-80$ & 10YR4/1 & - & $\mathrm{C}$ & $2, \mathrm{~m}, \mathrm{sbk}$ & $\mathrm{Fi}, \mathrm{sst}, \mathrm{spl}$ & $3, \mathrm{f}$ & $\mathrm{f}, \mathrm{fb}$ & Gs \\
\hline $\mathrm{Bt}_{3}$ & $80-101$ & $10 \mathrm{YR} 5 / 2$ & - & $\mathrm{C}$ & 2,C,sbk & $\mathrm{Fi}, \mathrm{sst}, \mathrm{spl}$ & $3, \mathrm{f}$ & $\mathrm{f}, \mathrm{fb}$ & Ds \\
\hline $\mathrm{Bt}_{4}$ & $101-128$ & 10YR6/2 & - & $\mathrm{C}$ & 2,C,sbk & Fi,st,pl & $3, \mathrm{f}$ & $\mathrm{f}, \mathrm{fb}$ & Gs \\
\hline $\mathrm{Bt}_{5}$ & $128-164$ & 10YR6/2 & - & $\mathrm{C}$ & 2,C,sbk & Fi,vst,pl & $3, \mathrm{f}$ & $\mathrm{f}, \mathrm{fb}$ & Gs \\
\hline $\mathrm{Bt}_{6}$ & 164-190 & $10 Y R 6 / 2$ & - & $\mathrm{C}$ & 2,C,sbk & Fi,vst,pl & $3, \mathrm{f}$ & $\mathrm{F}, \mathrm{fb}$ & - \\
\hline
\end{tabular}

SYMBOLS

Pores: $3=$ many, $2=$ common, $1=$ few; $c=$ coarse, $m=$ medium, $f=$ fine. $s$

Structure: 1 = weak, 2 = moderate, 3 = strong; abk angular blocky, sbk = sub-angular blocky, cr crumb, $m=$ massive.

Consistence: $1=$ loose, $\mathrm{fr}=$ friable, $\mathrm{fi}=$ firm; $\mathrm{nst}=$ non sticky, sst $=$ slightly sticky, $\mathrm{mst}=$ moderately sticky, $\mathrm{st}=$ sticky; $\mathrm{npl}=$ non plastic, $\mathrm{spl}=$ slightly plastic, $\mathrm{mpl}=$ moderately plastic, $\mathrm{pl}=$ plastic

Root: $\mathrm{f}=$ few, $\mathrm{c}=$ common, $\mathrm{a}-$ abundant; $\mathrm{fb}=$ fibrous, $\mathrm{w}=$ woody

Boundary: $\mathrm{c}=$ clear, $\mathrm{w}=$ wavy, $\mathrm{g}=$ gradual, $\mathrm{ir}=$ irregular; $\mathrm{d}=$ diffused, $\mathrm{b}=$ broken, $\mathrm{s}=$ smooth.

Texture: $\mathrm{LS}=$ loamy sand, $\mathrm{SL}=$ sandy loam, $\mathrm{SCL}=$ sandy clay loam, $\mathrm{SC}=$ sandy clay, $\mathrm{CL}=$ Clay loam, $\mathrm{C}=$ clay. 
Table 3: Some Physical Properties of the Soil Profile

\begin{tabular}{|c|c|c|c|c|c|c|c|}
\hline Horizon Depth & Sand Silt Clay & Texture Silt/Clay & Designation (cm) & $(\% \quad(\%)$ & Ratio & & \\
\hline \multicolumn{8}{|c|}{ AMAKAMA OLOKORO SOILS, $0.2 \%$ SLOPE, MID SLOPE } \\
\hline $\mathrm{Ap}_{1}$ & $0-13$ & 67 & 7 & 26 & \multicolumn{2}{|l|}{ Sand clay loam } & 0.25 \\
\hline $\mathrm{Ap}_{2}$ & $13-27$ & 69 & 4 & 27 & \multicolumn{2}{|l|}{ Sand clay loam } & 0.13 \\
\hline $\mathrm{Bo}_{1}$ & $27-63$ & 60 & 3 & 37 & \multicolumn{2}{|l|}{ Sand clay } & 0.08 \\
\hline $\mathrm{Bo}_{2}$ & $63-99$ & 60 & 3 & 37 & \multicolumn{2}{|l|}{ Sand clay } & 0.08 \\
\hline $\mathrm{Bo}_{3}$ & $99-127$ & 59 & 4 & 37 & \multicolumn{2}{|l|}{ Sand clay } & 0.09 \\
\hline $\mathrm{Bo}_{4}$ & $127-159$ & 58 & 5 & 37 & \multicolumn{2}{|l|}{ Sand clay } & 0.13 \\
\hline $\mathrm{Bo}_{5}$ & $159-210$ & 58 & 5 & 37 & \multicolumn{2}{|l|}{ Sand clay } & 0.13 \\
\hline $\mathrm{Bo}_{6}$ & $210-240$ & 60 & 5 & 35 & \multicolumn{2}{|l|}{ Sand clay loam } & 0.13 \\
\hline \multicolumn{8}{|c|}{ AJATA IBEKU SOILS, 0-5\%SLOPE, UPPER SLOPE } \\
\hline $\mathrm{Ap}_{1}$ & $0-9$ & 43 & 20 & 37 & Clay loan & \multicolumn{2}{|l|}{0.52} \\
\hline $\mathrm{Ap}_{2}$ & $9-28$ & 33 & 19 & 48 & Clay & \multicolumn{2}{|l|}{0.38} \\
\hline Bt & $28-60$ & 13 & 10 & 77 & Clay & \multicolumn{2}{|l|}{0.12} \\
\hline 2Btg & $60-80$ & 18 & 10 & 72 & Clay & \multicolumn{2}{|l|}{0.13} \\
\hline $2 \mathrm{Bssg}_{1}$ & 80-101 & 19 & 7 & 74 & Clay & \multicolumn{2}{|l|}{0.09} \\
\hline $2 \mathrm{Bssg}_{2}$ & $101-128$ & 22 & 5 & 73 & Clay & \multicolumn{2}{|l|}{0.06} \\
\hline $2 \mathrm{Bssg}_{3}$ & $128-164$ & 15 & 11 & 74 & Clay & \multicolumn{2}{|l|}{0.14} \\
\hline $2 \mathrm{Bssg}_{4}$ & $164-190$ & 19 & 12 & 69 & Clay & \multicolumn{2}{|l|}{0.17} \\
\hline
\end{tabular}

Table 4: Chemical properties of the soils

\begin{tabular}{|c|c|c|c|c|c|c|c|c|c|c|c|c|c|c|c|c|}
\hline \multirow{2}{*}{$\begin{array}{l}\text { DEPTH } \\
(\mathrm{cm})\end{array}$} & \multirow{2}{*}{$\begin{array}{l}\mathrm{pH} \\
\mathrm{H}_{2} \mathrm{O}\end{array}$} & \multirow{2}{*}{$\begin{array}{l}\mathrm{pH} \\
1 \mathrm{~N} \mathrm{KCl}\end{array}$} & \multicolumn{3}{|c|}{$\begin{array}{r}\text { Exchangeable Bases } \\
(\mathrm{cmol} / \mathrm{kg})\end{array}$} & \multirow{2}{*}{$\begin{array}{l}\mathrm{OC} \\
\mathrm{Na}\end{array}$} & \multirow{2}{*}{$\begin{array}{c}\text { Total N } \\
\%\end{array}$} & \multirow{2}{*}{$\begin{array}{l}\mathrm{C} / \mathrm{N} \\
\%\end{array}$} & \multicolumn{3}{|c|}{ Exch.Al Exch.H TEA } & \multicolumn{2}{|c|}{ Avail.P ECEC } & \multirow{2}{*}{$\begin{array}{l}\mathrm{B} / \mathrm{S} \\
\mathrm{cmol} / \mathrm{kg}\end{array}$} & \multirow[b]{2}{*}{$\%$} & \\
\hline & & & $\mathrm{Ca}$ & $\mathrm{Mg}$ & K & & & & ratio & $\mathrm{cmol} / \mathrm{kg}$ & $\mathrm{cmol} / \mathrm{kg}$ & $\mathrm{cmol} / \mathrm{kg}$ & $\mathrm{mg} / \mathrm{kg}$ & & & \\
\hline \multicolumn{16}{|c|}{ AMAKAMA OLOKORO SOILS, $0-2 \%$ SLOPE, MIDDLE SLOPE } & \\
\hline $0-13$ & 4.11 & 5.30 & 2.4 & 1.6 & 0.092 & 0.083 & 1.91 & 0.084 & 22.73 & 2.4 & 1.4 & 3.8 & 20.0 & 7.90 & 52 & \\
\hline $13-27$ & 4.45 & 5.40 & 2.0 & 1.2 & 0.076 & 0.083 & 1.16 & 0.084 & 13.80 & 1.2 & 1.4 & 3.6 & 6.50 & 6.96 & 48 & \\
\hline $27-63$ & 4.48 & 5.30 & 1.2 & 1.6 & 0.081 & 0.083 & 1.28 & 0.070 & 18.28 & 2.0 & 1.6 & 3.6 & 5.50 & 6.56 & 45 & \\
\hline $63-99$ & 4.55 & 5.60 & 1.6 & 0.8 & 0.071 & 0.075 & 0.54 & 0.056 & 9.64 & 1.8 & 1.2 & 3.0 & 17.00 & 5.55 & 46 & \\
\hline $99-127$ & 4.42 & 5.20 & 1.6 & 2.0 & 0.097 & 0.125 & 0.75 & 0.056 & 13.39 & 1.2 & 1.8 & 3.0 & 9.50 & 6.82 & 56 & \\
\hline $127-159$ & 4.71 & 5.25 & 2.0 & 1.6 & 0.071 & 0.075 & 0.33 & 0.028 & 11.78 & 0.8 & 1.6 & 2.4 & 13.00 & 6.15 & 61 & \\
\hline $159-210$ & 4.85 & 5.30 & 1.6 & 2.0 & 0.071 & 0.083 & 0.39 & 0.028 & 13.92 & 1.0 & 0.6 & 1.6 & 16.00 & 5.35 & 70 & \\
\hline $210-240$ & 5.32 & 5.50 & 2.0 & 1.6 & 0.061 & 0.075 & 0.29 & 0.042 & 6.90 & 0.8 & 2.0 & 2.8 & 4.00 & 6.54 & 57 & \\
\hline \multicolumn{16}{|c|}{ AJATA IBEKU SOILS, 0 - 5\% SLOPE, UPPER SLOPE } & \\
\hline $0-9$ & 4.83 & 5.50 & 4.0 & 2.4 & 0.133 & & 83 & 0.92 & 0.098 & 9.38 & 0.6 & 1.2 & 1.8 & 20.0 & 8.42 & 79 \\
\hline $9-28$ & 4.38 & 5.15 & 2.4 & 0.8 & 0.112 & & 83 & 1.64 & 0.112 & 14.64 & 4.4 & 3.6 & 8.0 & 8.5 & 11.39 & 30 \\
\hline $28-60$ & 4.28 & 4.85 & 3.2 & 1.6 & 0.122 & & 92 & 0.72 & 0.056 & 12.85 & 5.0 & 4.6 & 9.6 & 21.0 & 14.61 & 35 \\
\hline $60-80$ & 4.48 & 4.95 & 2.8 & 2.0 & 0.174 & & 83 & 0.95 & 0.070 & 13.57 & 16.0 & 12.4 & 28.4 & 9.0 & 33.46 & 15 \\
\hline $80-101$ & 4.53 & 4.80 & 4.4 & 3.2 & 0.153 & & 00 & 0.95 & 0.070 & 13.57 & 18.0 & 13.4 & 31.4 & 8.5 & 39.25 & 20 \\
\hline $101-128$ & 4.57 & 4.70 & 8.0 & 4.0 & 0.199 & & 08 & 1.16 & 0.042 & 27.6 & 17.0 & 15.0 & 32.0 & 12.0 & 44.31 & 27 \\
\hline $128-164$ & 4.30 & 4.10 & 9.6 & 6.4 & 0.204 & & 83 & 0.78 & 0.042 & 18.57 & 14.2 & 10.4 & 24.6 & 9.5 & 48.89 & 33 \\
\hline $164-190$ & 3.91 & 4.90 & 11.2 & 11.6 & 0.199 & & 00 & 1.10 & 0.056 & 19.64 & 6.8 & 11.6 & 18.4 & 5.5 & 41.50 & 56 \\
\hline
\end{tabular}

TEA = Total Exchangeable Acidity, ECEC = Effective Cation Exchange Capacity, B/S = Base Saturation

Ohaeri J. E. and Eshett E. T.

Table 5 Mean values of various forms of phosphorus in the soil in $\mathrm{mg} / \mathrm{kg}$ 


\begin{tabular}{|c|c|c|c|c|c|c|c|}
\hline $\begin{array}{l}\text { Depth } \\
\text { (cm) }\end{array}$ & $\begin{array}{l}\text { AIP } \\
\mathrm{mg} / \mathrm{kg}\end{array}$ & $\begin{array}{l}\mathrm{Fe}-\mathrm{P} \\
\mathrm{mg} / \mathrm{kg}\end{array}$ & $\begin{array}{l}\mathrm{Ca}-\mathrm{P} \\
\mathrm{mg} / \mathrm{kg}\end{array}$ & $\begin{array}{l}\text { Organic P } \\
\mathrm{mg} / \mathrm{kg}\end{array}$ & $\begin{array}{l}\text { Occluded P } \\
\mathrm{mg} / \mathrm{kg}\end{array}$ & $\begin{array}{l}\text { Total P } \\
\text { mg/kg }\end{array}$ & $\begin{array}{l}\text { Bray 2P } \\
\mathrm{mg} / \mathrm{kg}\end{array}$ \\
\hline \multicolumn{8}{|c|}{ AMAKAMA OLOKORO SOILSL } \\
\hline $0-13$ & 27.29 & 68.07 & 20.70 & 69.71 & 38.62 & 224.39 & 20.00 \\
\hline $13-27$ & 45.70 & 59.62 & 11.35 & 103.34 & 65.35 & 285.36 & 6.50 \\
\hline $27-63$ & 28.79 & 29.24 & 3.94 & 44.03 & 152.53 & 258.53 & 5.50 \\
\hline $127-159$ & 13.26 & 35.09 & 6.41 & 74.90 & 76.43 & 206.09 & 13.00 \\
\hline $159-210$ & 23.39 & 43.38 & 16.26 & 54.19 & 38.38 & 175.60 & 16.00 \\
\hline $210-240$ & 20.32 & 33.14 & 2.36 & 75.87 & 169.52 & 301.21 & 4.00 \\
\hline \multicolumn{8}{|c|}{ AJATA IBEKU SOILS } \\
\hline $0 \_-9$ & 16.77 & 89.52 & 6.20 & 113.09 & 608.56 & 834.14 & 20.00 \\
\hline $101--128$ & 30.20 & 52.64 & 7.89 & 70.35 & 282.82 & 443.90 & 12.00 \\
\hline $128--164$ & 29.59 & 33.02 & 2.14 & 83.84 & 405.06 & 553.65 & 9.50 \\
\hline $164--190$ & 50.20 & 95.12 & 27.29 & 127.71 & 952.13 & 1252.45 & 5.50 \\
\hline
\end{tabular}

Table 6: Content of various forms of phosphorus in the soils

\begin{tabular}{lccccccc}
\hline LOCATION & AL $-\mathbf{P}$ & Fe $-\mathbf{P}$ & $\mathbf{C a}-\mathbf{P}$ & Org. P & Occluded P & Total P & Avail. P \\
\hline AMAKAMA & 23.29 & & & & & & \\
AJATA & 36.28 & 41.07 & 8.55 & 61.00 & 103.50 & 237.50 & 11.43 \\
\hline
\end{tabular}

Table 7 Correlation coefficient between soil phoshorus and some soil properties

\begin{tabular}{lclllll}
\hline & Al- P & Fe-p & Ca-p & Org-p & Occluded p & Total p \\
\hline Bray 2 p & 0.23 & -0.05 & 0.17 & 0.11 & -0.20 & -0.17 \\
pH (water) & 0.06 & 0.01 & -0.17 & 0.08 & $-0.30^{*}$ & -0.270 \\
Exch Ca & 0.10 & 0.16 & 0.03 & 0.19 & $0.61^{* * *}$ & $0.61^{* * *}$ \\
Exch Al & 0.23 & 0.08 & -0.02 & 0.10 & 0.22 & 0.24 \\
O/C & 0.19 & 0.24 & $0.29^{*}$ & 0.05 & 0.14 & 0.18 \\
Sand & 0.14 & -0.09 & $0.29^{*}$ & 0.08 & $0.57^{* * *}$ & $0.57^{* * *}$ \\
Clay & 0.06 & -0.03 & 0.19 & -0.001 & $0.49^{* *}$ & $0.47^{* *}$ \\
\hline
\end{tabular}


Multiple correlation analysis (Table 7) showed that the level of organic $\mathrm{P}$ in these soils with organic carbon contrary to the reports of Uzu et al. (1975), Udo and Ogunwale (1977), Udo and Dambo (1979). But it was in agreement with the reports of Loganathan and Sutton (1987), Osodeke and Kamalu (1992).

Inorganic $\boldsymbol{P}$ The amount and distribution of various forms of inorganic $\mathrm{P}$ are shown in Table 6. . The occluded $P$ on the average was 103.5 $\mathrm{mg} / \mathrm{kg}$ in the Amakama soil derived from Coastal Plain Sands and $452.64 \mathrm{mg} / \mathrm{kg}$ in the Ajata soils derived from Shale. Occluded P constituted 40 to $80 \%$ of total inorganic $\mathrm{P}$ forms in the soil. Fe-P ranged from 27.29 to.68.07 $\mathrm{mg} / \mathrm{kg}$ in the Amakama soils derived from Coastal Plain Sands, and 33.02 to $95.12 \mathrm{mg} / \mathrm{kg}$ in the Ajata soil (Shale). The occluded $\mathrm{P}$ constituted between 26 and 68 percent of the total $\mathrm{P}$ in the various soils. The ranges of percentage of occluded $\mathrm{P}$ to total inorganic $\mathrm{P}$ and total $\mathrm{P}$ are in firm agreement with the report of Osodeke and Kamalu (1992) (30 to 80\% and 11 to $67 \%$ of occluded $\mathrm{P}$ to total inorganic $\mathrm{P}$ and occluded $\mathrm{P}$ to total $\mathrm{P}$ respectively). The occluded $\mathrm{P}$ and Fe- $\mathrm{P}$ occupied more than $84 \%$ of the total inorganic P. This indicates the high degree of chemical weathering of these soils (Chang and Jackson, 1958). The content of Ca-P and Al-P are very low ( $<16 \%$ of the total inorganic $\mathrm{P}$ ) especially in the soils derived from Sandstone (Amakama). This is in agreement with the report of Uzu et al. (1975). The low Al-P content and the predominance of the occluded $\mathrm{P}$ in these soils suggest the limited capacity of these soils in supplying plant-available $\mathrm{P}$ from the inorganic P (Chang and Juo, 1963; Smith, 1965; Juo and Ellis, 1968b). The active $\mathrm{P}$ constitute between 18 and $38 \%$ percent of the total soil $P$. These values are comparable to the values of 13 to 33 percent reported by Osodeke and Kamalu (1992). The relative abundance of various forms of inorganic $\mathrm{P}$ was increasing in order of Ca-P, Al-P, Fe-P, and occluded $\mathrm{P}$ (figure 1). This order has been reported by several authors (Udo and Uzu, 1972; Udo and Ogunwale, 1977; Udo and Dambo, 1979; Loganathan et al., 1982; Loganathan and Sutton, 1987; Osodeke and Kamalu, 1992; Ojo et al., 2010). The high content of Al-P in the lower horizons of the Ajata soil is due to poor drainage condition rather than degree of weathering. Similar reports were obtained from Juo and Ellis (1968b), Westin and de Brito (1969), and Uzu et al. (1975). Calcium-P correlated negatively with sand and positively with organic carbon, exchangeable $\mathrm{Ca}, \mathrm{Al}-\mathrm{P}$ and total P. Fe-P correlated positively with organic $\mathrm{P}$, Al-P and total P. Al-P correlated positive with Fe-P, Ca-P, and organic P. Occluded P correlated positively with clay and exchangeable
Ca and negatively with sand. Available $P$ The Bray $\mathrm{P} 2$ test values are shown in Table 4. The available $\mathrm{P}$ ranged from $4.0 \mathrm{mg} / \mathrm{kg}$ in the Amakama soil to $21 \mathrm{mg} / \mathrm{kg}$ in the Ajata soil with mean value of $11.59 \mathrm{mg} / \mathrm{kg}$. In all the studied soils, the surface horizon (Ap) contained more available $\mathrm{P}$ than the subsurface horizons. The available $\mathrm{P}$ in Amakama and Ajata soils is the same.

In general the soils of studied area had less available $P$ than the critical levels of 15 $\mathrm{mg} / \mathrm{kg}$ by the Bray P 2 method (Enwezor et al., 1989; Enwezor et al., 1990).

\section{CONCLUSION}

The result of various forms of phosphorus indicated that the pattern of their distribution with depth was not uniform in all the soils studied. The relative abundance of various forms of inorganic $\mathrm{P}$ were in the sequence of $\mathrm{Ca}-\mathrm{P}<$ Al-P $<$ Fe-P $<$ occluded P. In all the studied soils, the surface soils contain more available $\mathrm{P}$ than the subsurface soil. In general, the soil available $\mathrm{P}$ is below the critical level (15 $\mathrm{mg} / \mathrm{kg}$ ).

It could be concluded therefore, that the status of the total phosphorus as well as the various forms they exist in the soils studied depend upon the type of different parent materials from which these soils were formed. Therefore, parent materials have very significant influence on the overlaying soils when the soil is formed in-situ from parent material.

\section{REFERENCES}

Adepetu, J. A. (1972). Evaluation of the kinetic sorption and its implications in $P$ availability to plants growths in soil. $\mathrm{Ph}$. D. Thesis Paredue University.

Akamigbo, F. O. R. and C. L. A. Asadu (1976). The Influence of parent materials on

soils of Southeastern Nigeria. East Africa Agricultural and Forestry Journal. 48:8191

Ayodele, O. J. (1980). Calibration and correlation studies of phosphorus in Savannah soils of Southwestern Nigeria. PH.D. Thesis University of Ibadan, Nigeria.

Bouyoucos, G. H. (1962). Hydrometer method Ohaeri J. E. and Eshett E. T. ticle size Society of America Proceedings.26:464-465.

Brady, N. C. and R.R Weli (2002). The nature and properties of Soils.13 ${ }^{\text {th }}$ edition Preltice Hall Inc. Englewood Cliff New Jessey. 
Bray, R. H. and L. T. Kurtz (1945). Determination of total, organic and available

forms of phosphorus in soils. Soil Science. 59 : $39-45$.

Bremner,J. M. (1996). Nitrogen-Total. In: chemical methods of soil Analysis part 3 (eds. Sparks, D. L., A. L. Page, P. A. Helmke, R. H. Loeppert, P. N. Soltanpour, M. A., Tabatabai, C. T. Johnson, and M. E. Summer). Soil Science Society of American Book series, American Society of Agronomy, Madison U.S.A. PP 1085-1121.

Chang, S. C. and M. L. Jackson (1957). Fractionation of soil phosphorus.Soil Science. 84: 113-144.

Chang, S. C. and M. L. Jackson (1958). Soil phosphorus fractionation in some representative soils. Journal of Soil Science. 9: 109-119.

Chang, S. C. and A. S. R. Juo (1963). Available phosphorus in relation to forms of phosphorus in soils. Soil Science. 95: 91-96.

Coleman, N. T. and G. W. Thomas (1967). The basic chemistry of soil acidity In. Soil acidity and Liming. Agronomy Monograph (eds R. W. person and F. Adams) 12:1-41. American Society Agronomy, Madison Wisconsim.

Enwezor, W. O. (1977). Soil testing for phosphorous in some Nigerian soils. I comparison of methods of determining available phosphorus in soils of southeastern Nigerian. Soil Science. 122: $48-53$.

Enwezor, W.O., A. C. Ohiri, E. E. Opuwaribo and E. J. Udo (1990). Literature revie on soil fertility investigations in Nigeria. Federal Ministry of Agriculture and Natural Resources, Lagos.

Enwezor, W. O., E. J. Udo and A. R. Sobulo (1991). Fertility status and Productivity of Acid Sands. In Acid Sands of Southeastern Nigerian Monograph No. 1. Soil Science Society of Nigeria. 5673.

Enwezor, W. O., E. J. Udo, N. J. Usoroh, K. A. Ayotade, J. A. Adapetu, V. O. Chude and C. I. Udegbe (1989). Fertilizer use and management practices crops in Nigeria. Series No. 2 published by Bobma publishers, Ibadan.

F.A.O./UNESCO. (1988). Soil map of the World. 1:5000000.Revise Legand. World report. NO.60. F.A.O. Rome.

GenStat (2011). Genstat for window. Release 10.3 Discovery $4^{\text {th }}$ Edition (PC/ windo 7). VSN international Ltd. Hemel Hempstead UK. www.discovery.genstat.co.uk.

Jackson, M. L. (1958). Soil chemical analysis. Prentice Hall, New York. Pg 498.

Jungerius, P. D. (1964). Soils of Eastern Nigeria. Publ. Service Geolograque du Luxembourg. 14:185-198.

Juo, A. S. R. and B. G. Ellis ( 1968b). Chemical and physical properties of $\mathrm{Al}$ and $\mathrm{Fe}$

phosphate and their relation to $\mathrm{P}$ availability. Soil Science Society America Proceedings. 32: 216-221.

Juo, A.R.S. and R. L. Fox (1974). Phosphate sorption characteristics of some benchmark soils of West African. Soils Science. 124: 370 - 376.

Leg, J. O. and C.A. Black (1955). Determination of organic phosphate in soils 2.Ignition method. Soil science society of American proceedings. 19:139-142.

Loganathan P., M. N. Dayaratne and Shanmuganathan (1982). Evaluation of thephosphorus status of some coconut growing soils of sir lanka. Journal Agricultural Science. 99: 25 - 33.

Loganathan, P. and P. M. Sutton (1982). Phosphorus Fractions and availability in soils formed on different geological deposit in the Niger Delta area of Nigeria. Soils Science. 143:16-25.

Mclean, E. O. (1982). Soil $\mathrm{pH}$ and lime requirement. In methods of soil Analysis, Part 2(ed. A. L. Page et al.) Soil Science Society of American Book Series. American Society of Agronomy, Madison. U.S.A. PP 199-224.

Mehta, B.V and J.M. Patel (1963). Some aspects of phosphorus in Gujaret soils. Journal Indian Society Soil Science. 11:151158.

Murphy, J. and J. P. Riley (1962). A modified single solution method for the determination of $\mathrm{P}$ in natural waters. Analytical Chemistry Acta 27: 31-36.

Nelson, D. W. and Sommers, L. E. (1996). Total carbon, organic carbon and organic matter. In chemical methods of soil analysis, part 3 (eds. Sparks, D. L., A. L. Page, P.

A. Helmke, R. H. Loeppert, P. N. Soltanpour, M. A., Tabatabai, C. T. Johnson, and M. E. Summer). SSSA Book series No 5 American Society of Agronomy, Madison U.S.A. PP 961-1010.

Ojo, A. O., Adelase, A. O., Sokalu, A. O. and Adetunji, M. T. (2010). Soil fertility and phosphorus fractions in response to poultry manure and phosphorus fertilizers application under a maize 
monoculture system. Proceedings of the $34^{\text {th }}$ annual conference of the soil science society of Nigeria held in IAR\&T Ibadan. March 22 - 25, 2010. Pp 160-164.

Osodeke, V. E., D. O. K. Asawalam, O. J. Kamalu and I. K. Ugwu (1991).Phosphorus sorption characteristics of some soils of rubber belt of Nigeria. Paper presented at the $19^{\text {th }}$ Annual conference of Soil Science Society of Nigeria, 17-21 November 1991, Nigeria.

Osodeke, V. E. and O. J. Kamalu (1992). Phosphorus status of Hevea growing soils of Nigeria. Indian Journal of natural Rubber Research 5:107-112.

Peterson, G. W. and R. B. Corey (1966). A modified Chang and Jackson procedure for routine fractionation of inorganic soil P. Soil Science Society American Proceedings. 30: 563-565.

Potash and Phosphate Institute (PPI). (1990). Phosphorus in soil fertility manual.

Smith, A. N. (1965). The supply of soluble phosphorus to the wheat from inorganic soil phosphorus. Plant Soil. 22: 314316.

Soil Survey Staff. (2006). Key to Soil Taxonomy. USDA - NRCS. $10^{\text {th }}$ edition U.S.A. Govt. printing office. Washington ,D.C.

Thomas, G. W. (1996). Soil pH and soil acidity. In chemical methods of soil Analysis part 3 (eds. Sparks, D.L., A.L. Page, P.A. Helmke, R.H. Loeppert, P.N. Soltanpour, M.A., Tabatabai, C.T. Johnson, and M.E. Summer). Soil Science Society of American Book series, American Society of
Agronomy, Madison U.S.A. PP 475490.

Udo, E.J. and Dambo, V.I. (1979). Phosphorus status of Nigerian coasted plain sands. Journal Agricultural Science. Cambridge. 93:281 - 289.

Udo, E. J. and J. A. Ogunwale (1977). Phosphorus fractions in selected Nigerian soils. Soil Science SocietyAmerican Journal. 41: 1141 1146.

Udo, E. J. and F. O. Uzu (1972). Characteristics of phosphorus adsorption by some Nigerian soils. Soil Science Society American Proceedings. 36: 879-883.

Uzu, F. O., A. S. R. Juo and A. A. A. Fayemi (1975). Forms of phosphorus in some important Agricultural soils of Nigeria. Soil Science. 120: 212 - 218.

Walkley, A. and I. A. Black (1934). Examination of the Degtgareff method of determination of organic matter and proposed modification of chromic acid titration method. Soil Science. 37: 2238.

Westin, F. C and de Brito,J. G. (1969). Phosphorus fractions in some Venezuelan soils as related to their stage weathering. Soil Science. 107: 194-202. 